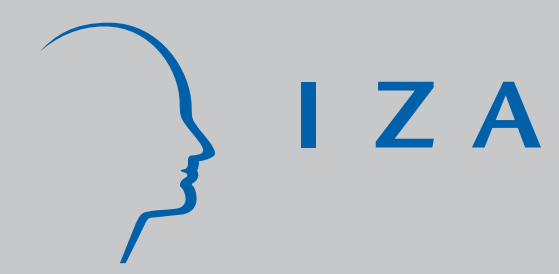

IZA DP No. 590

Why Do Foreign-Owned Firms Pay More?

The Role of On-the-J ob Training

Holger Görg

Eric Strobl

Frank Walsh

October 2002 


\title{
Why Do Foreign-Owned Firms Pay More? The Role of On-the-Job Training
}

\author{
Holger Görg \\ Eric Strobl \\ University College Dublin \\ Frank Walsh \\ University College Dublin
Discussion Paper No. 590
October 2002 \\ IZA \\ P.O. Box 7240 \\ D-53072 Bonn \\ Germany \\ Tel.: +49-228-3894-0 \\ Fax: +49-228-3894-210 \\ Email: iza@iza.org
}

University of Nottingham and IZA Bonn

This Discussion Paper is issued within the framework of IZA's research area Internationalization of Labor Markets. Any opinions expressed here are those of the author(s) and not those of the institute. Research disseminated by IZA may include views on policy, but the institute itself takes no institutional policy positions.

The Institute for the Study of Labor (IZA) in Bonn is a local and virtual international research center and a place of communication between science, politics and business. IZA is an independent, nonprofit limited liability company (Gesellschaft mit beschränkter Haftung) supported by the Deutsche Post AG. The center is associated with the University of Bonn and offers a stimulating research environment through its research networks, research support, and visitors and doctoral programs. IZA engages in (i) original and internationally competitive research in all fields of labor economics, (ii) development of policy concepts, and (iii) dissemination of research results and concepts to the interested public. The current research program deals with (1) mobility and flexibility of labor, (2) internationalization of labor markets, (3) welfare state and labor market, (4) labor markets in transition countries, (5) the future of labor, (6) evaluation of labor market policies and projects and (7) general labor economics.

IZA Discussion Papers often represent preliminary work and are circulated to encourage discussion. Citation of such a paper should account for its provisional character. A revised version may be available on the IZA website (www.iza.org) or directly from the author. 
IZA Discussion Paper No. 590

October 2002

\section{ABSTRACT}

\section{Why Do Foreign-Owned Firms Pay More? The Role of On-the-Job Training*}

Foreign-owned firms have consistently been found to pay higher wages than domestic firms to what appear to be equally productive workers in both developed and developing countries alike. Although a number of studies have documented and some attempted to explain this stylized fact, the issue still remains unresolved. In a multi-period bargaining framework we show that if firm specific training is more productive in foreign firms, foreign firm workers will have a steeper wage profile and thus acquire a premium over time. Using a rich employeremployee matched data set we show that the foreign wage premium is only acquired by workers over time spent in the firm and only by those that receive on the job training, thus providing empirical support for a firm specific human capital acquisition explanation.

JEL Classification: J24, F23

Keywords: on-the-job training, foreign firms, wages

Corresponding author:

Holger Görg

School of Economics

University of Nottingham

Nottingham NG7 2RD

UK

Tel.: +44 (0) 1158466393

Fax: +44 (0) 1159514159

Email: holger.gorg@nottingham.ac.uk

\footnotetext{
* We are particularly grateful to Francis Teal and the CSAE at Oxford for the provision of and advice on the data. Thanks are also due to Spiros Bougheas, Richard Upward and seminar participants at the Stockholm School of Economics for helpful comments on an earlier draft. Holger Görg gratefully acknowledges financial support from the Leverhulme Trust (Programme Grant F114/BF).
} 


\section{Section I: Introduction}

It appears to be accepted wisdom that foreign firms pay higher wages than their domestic counterparts in the host country and a sizeable body of literature now provides evidence to substantiate this fact for both developed and developing countries. While the existence of a foreign firm wage premium does generally not appear to be in dispute, its causes are, however, as of yet unresolved. For example in the case of developing countries, while Lim (1977) using industry and establishment data for Malaysian manufacturing finds that part of the premium can be explained by higher levels of capital intensity and greater capacity utilization of foreign firms, a significant unaccounted for differential remains. Similarly, Aitken, Harrison and Lipsey (1997) and Lipsey and Sjöholm (2001) using establishment level data find wage differentials in Mexico and Venezuela, and Indonesia respectively, which cannot be explained away by plant characteristics such as size and capital intensity. Te Velde and Morrisey (2001) use a matched employer-employee database for five African countries which allows them to control for ownership and size of the firm and for workers' characteristics. Their econometric estimations show that foreign ownership is associated with around 20-40 percent higher wages, controlling for age, tenure and education of the individuals. This wage gap is halved once they also account for firm and sector specific factors. They explain the remaining wage gap arguing that either foreign firms employ higher technologies and/or that workers in foreign firms are more effective at rent sharing. However, they cannot test these hypotheses directly.

For developed countries, Aitken, Harrison and Lipsey (1997) find that there are wage differences between foreign and domestic manufacturing firms in the US. Similar evidence is provided by Doms and Jensen (1998) and Feliciano and Lipsey (1999) for the US, and Globerman, Ries and Vertinsky (1994) for Canada. These studies discover that a large part, though not all, of the foreign wage premium can be explained by the sectoral 
location of foreign and domestic firms, and by foreign firms being larger and more capital-intensive. Girma, Greenaway and Wakelin (2001) find for UK manufacturing establishments that foreign firms pay, on average, about 5 percent higher wages than domestic firms, even when sector, establishment size and productivity are controlled for. Griffith and Simpson (2002) also report higher wages for skilled and unskilled workers in foreign firms in UK manufacturing, controlling for sector, size and age of the establishment.

The current paper revisits the "stylised fact" of the foreign-domestic wage differential both theoretically and empirically. To the best of our knowledge this is the first paper to provide a formal theoretical explanation to why we would expect foreign firms to pay higher wages, the papers cited above only investigate this issue empirically. Our theoretical model assumes that firm specific training (on-the-job training) is more productive in foreign firms. This may partly be due to foreign firms having access to firm specific assets that give them a technological advantage over domestic firms in the same industry (see, Caves, 1996), or foreign-owned firms having better access to capital which allows them to invest in better technology. Under this assumption, our model shows that workers in foreign firms will have a steeper wage profile than workers in domestic firms as they benefit more from training. Thus, they acquire a wage premium from working in a foreign firm over time.

We investigate the predictions generated by our model using a rich employeremployee matched dataset for manufacturing firms in Ghana. This dataset allows us to control in the wage regressions not only for firm level characteristics, but also for a number of human capital variables. In particular, in line with the theoretical model, we can distinguish between whether individuals work in domestic or foreign owned firms, and whether they receive on-the-job training (OJT). Our econometric estimations provide empirical support for the theoretical predictions. Specifically, we find that while 
there are no differences in starting wages between workers in domestic or foreign firms, workers receiving OJT in foreign firms experience higher wage growth than those working and receiving OJT in domestic firms.

The remainder of the paper is structured as follows. Section II sets out the theoretical model. Section III discusses the data while Section IV presents the results of the econometric estimations. Finally, Section V concludes.

\section{Section II: Theoretical Framework}

In this section we develop a model of firm specific human capital accumulation to explain the foreign firm wage premium. We assume that firm specific training is more productive in foreign firms. This could be either due to the foreign firm's access to firm specific assets which give foreign firms a technological advantage (Caves, 1996), or to foreign firms having better access to capital (which can easily be sourced abroad) to allow them to invest in more technology intensive capital goods which, in turn, requires better trained workers. Given this assumption we show in a multi-period bargaining model with identical workers that foreign firm workers will have a steeper wage profile.

The impact of firm specific training on wages is sometimes analysed using Hashimoto's (1981) model where competition ensures that the contract maximizes expected joint surplus in an uncertain world. Alternatively two period bargaining models are often used to solve for the pre and post training wage. See Malcolmson (1999) for a discussion on these models or Acemoglu and Pischke (1999a) or Booth and Chatterji (1998) for recent applications. Accordingly, human capital acquisition is chosen in period one by the firm. Firms make the choice of human capital acquisition anticipating a second period wage bargain which will condition on this and the first period wage is determined by a participation condition. If on the job training is more productive in foreign firms relative to domestic firms the bargaining model mentioned above would 
predict a higher second period wage in foreign firms. However, it also necessitates a lower starting wage in foreign firms. Another implication of the bargaining model that has been used to analyse firm specific capital accumulation is that because the surplus bargained over in the second period is not net of the costs of training, under-investment may occur (see Malcolmson, 1999, p. 2313, for a discussion on this).

In the bargaining framework developed in our paper the costs of training accrue gradually as the worker gets trained rather than being sunk at the start of the contract as in the models mentioned above. The implication is that firms and workers bargain over the surplus net of training costs and efficient investment occurs. Also we assume workers have bargaining power even in the first period in contrast to earlier models. A ny failure to agree even in the first period of the contract will reduce the acquisition of human capital and lower the stream of surplus for the remainder of the contract. The model has many periods thus allowing us to predict what the workers tenure wage profile might look like. In this model starting wages may be the same for foreign and domestic workers although workers receiving more training (those employed in foreign firms) will experience higher wage increases. We assume that apart from satisfying a participation constraint, firm's and worker's outside options are irrelevant to the bargaining game. This is in line with the argument in Sutton (1986) that in the absence of uncertainty the outside option does not provide a credible threat in a bargaining game unless it is better than what is being offered.

\section{The model}

A worker has some initial productivity which we will normalize to zero, but also acquires human capital that is specific to the firm during each period he stays with the firm. Normalising initial productivity means we interpret the wages derived below as the net addition to the basic wage in any period arising from firm specific capital 
accumulation. The human capital acquired in any period increases the workers productivity with the firm in each subsequent period the worker stays with the firm according to the production function $G\left(H_{i}\right)$, where $G\left(H_{i}\right)>0$ and $G^{\prime \prime}\left(H_{i}\right) \leq 0$ and the stock of human capital in any period $i$ is

$$
H_{i}=h_{0}^{n} \sum_{j=1}^{i-1} \beta^{i-j} h_{j}
$$

The addition to the stock in any period is $h_{i}$ and human capital depreciates by a fraction $1-\beta$ in each period. We assume the discount rate is unity for simplicity. We also assume that workers arrive with an endowment of human capital $h_{0}^{n}$ which is complementary in production to specific capital. The superscript $n=(f, d)$ denotes a foreign or domestic firm and allows for the fact that the degree of complementarity between general and specific skills may differ across these. The risk neutral firm and worker bargain over the wage in each of the $T$ periods. In each period workers and firms meet at the beginning of the period and alternating offers are made until one party accepts the others offer. The constant fraction of a periods output lost each time the worker delays production to make an offer is $\delta^{w}$ while $\delta^{f}$ is the share lost each time a firm makes an offer. The wage in any period $j, w_{j}$ represents the worker's share of the output in that period. The firm's profit in any period is

$$
\pi_{j}\left(H_{j}, h_{j}\right)=G\left(H_{j}\right)-c\left(h_{j}\right)-w_{j}
$$

The cost of any additional human capital acquired in period $i$ is $c\left(b_{i}\right)$ where $c^{\prime}(b)>0$, $c^{\prime \prime}(b)>0$. For the moment we take the amount of human capital in each period as being exogenously determined, although this assumption is relaxed below. Output net of human capital costs is

$$
F\left(H_{T-i}, h_{T-i}\right)=G\left(H_{T-i}\right)-c\left(h_{T-i}\right)
$$


The appendix shows that in a multi-period bargaining framework, the wage and profit in each period will be a constant fraction of the surplus generated in each period:

$$
\begin{aligned}
& w_{T-i}=\frac{\delta^{w}}{\delta^{w}+\delta^{f}} F\left(H_{T-i}, h_{T-i}\right) \\
& \pi_{T-i}=\frac{\delta^{F}}{\delta^{w}+\delta^{f}} F\left(H_{T-i}, h_{T-i}\right)
\end{aligned}
$$

To understand the intuition behind this result one needs to first recognize that workers bargain in each period, even in the first period. Because human capital is acquired on the job, failure to reach an agreement leads to a reduction in human capital accumulation, which will reduce the future surplus to be bargained over. The impact of failure to agree on future surplus will have a symmetric effect on the firm and worker's optimal offers in the bargaining game leading to the solution on equations (4) and (5). It is clear from (4) that if human capital accrues at a higher rate in the foreign sector that sector will have a steeper wage profile. We will see in the example below that the foreign sector may or may not have higher starting wages.

\section{Endogenising the choice of human capital}

We assume that at the beginning of each period the firm chooses $h_{i}$. While the costs increase in human capital at an increasing rate we assume that these costs accrue at a uniform rate within each period and so do not affect the bargaining game. Anticipating the solution to the bargaining game implied by (5) the firm will choose human capital in each period to maximize the stream of profit over the contract subject to both the worker's and firm's participation constraint.:

$$
\sum_{i=1}^{T}\left[G\left(h_{0}^{n} \sum_{j=1}^{i} \beta^{i-j} h_{j}\right)-c\left(h_{i}\right)\right] \frac{\delta^{f}}{\delta^{w}+\delta^{f}}
$$


The worker who has alternative wage $v$ will stick with the contract if at any period $i$ if:

$$
\sum_{j=i}^{T}\left[w_{j}-v\right] \geq 0
$$

The participation constraint for the firm assuming an alternative profit of $\bar{\pi}$ is:

$$
\sum_{j=i}^{T}\left[\pi_{j}-\bar{\pi}\right] \geq 0
$$

The firm has to choose a level of human capital in the first period, which affects productivity in all subsequent periods. Again we solve this problem by backward induction. In the final period the firm does not invest in any new human capital since new investments are only productive in the subsequent period. In the second last period the firm takes all the human capital it accrued over the previous periods as given and chooses additional human capital to be used in the final period. The first order condition for this problem allows us solve for $h_{T-1}$ conditional on the human capital in the previous periods. In period T-2 human capital for periods up until T-2 are taken as given. Given the solution to the period T-1 problem the level of human capital in T-2 can be solved. We continue working back to the first period. This is illustrated in a very simple example in the next section.

As in standard human capital models $h_{i}$ will decrease as the contract gets nearer the end. The wage in any period is given in (4). The stock of human capital, the surplus and thus the wage is non-decreasing with tenure. The efficient level of on the job training will be achieved since both workers and the firm share in the costs and benefits of any investments. It is worth pointing out that credit constraints, minimum wages or other features constraining the starting wage would leave the firms choice of human 
capital in any period unaffected in our model. ${ }^{1}$ The wage in any period will be the maximum of the minimum wage or the wage given in equation (4). Thus credit constraints or a binding minimum wage could lower the profitability of the contract and thereby affect the firm's participation decision.

\section{An Example}

We now illustrate in an example how the above model can be used to explain wage differentials between foreign and domestic firms. Assume that both types of firms, foreign and domestic have a production function

$$
G(H)=\alpha^{n} H
$$

with $n=(f, d)$. Foreign firms can be assumed to provide more productive training, due to firm specific assets or the use of more technology intensive production, and may have more on the job training opportunities. ${ }^{2}$ Thus, we assume that $f>d$ in equation (9). Furthermore, we assume that the price of output is unity in both sectors and firms have a common cost function for acquiring human capital in any period,

$$
c(h)=\frac{h^{\sigma}}{\sigma}
$$

The profit maximization problem in period $i$ can be written as follows

$$
\max _{h_{i}}\left[\alpha h_{0}^{n} \sum_{j=i}^{T-1} \sum_{k=1}^{j} \beta^{j-k} h_{k}-\frac{h_{i}^{\sigma}}{\sigma}\right] \frac{\delta^{f}}{\delta^{w}+\delta^{f}}
$$

The firm chooses human capital accounting for the impact on output in all subsequent periods. We solve by backward induction choosing human capital in the final

\footnotetext{
${ }^{1}$ Acemoglu and Pischke (1999b) provide a recent review of the literature on minimum wages and training and conclude that there is no clear evidence that minimum wages reduce training. ${ }^{2}$ For example, Sousa (2001) finds for the UK that foreign-owned firms are more likely to provide training, and spend more on training than comparable domestic firms. Gershenberg (1987) discusses and provides evidence on the importance of training activities by multinationals in Kenya.
} 
period first. The first order condition implies that the level of human capital in any period $i$ would be

$$
h_{i}=\left(\alpha^{n} h_{0}^{n}\right)^{\frac{1}{\sigma-1}}\left[\sum_{j=i}^{T-i} \beta^{j-i}\right]^{\frac{1}{\sigma-1}}
$$

This is positive but decreasing as tenure increases and it is independent of the firm's or worker's bargaining power. Using the above expression for human capital in equation (4) we can calculate the wage in period i:

$$
w_{i}=\frac{\left[\alpha^{n}\right]^{\frac{\sigma}{\sigma-1}} \delta^{w}}{\delta^{w}+\delta^{f}}\left[\left(h_{0}^{n} \sum_{j=1}^{i} \sum_{k=j}^{T-j} \beta^{k-j}\right)^{\frac{1}{\sigma-1}}-\left(\frac{h_{0}^{n}}{\sigma} \sum_{j=i}^{T-i} \beta^{j-i}\right)^{\frac{\sigma}{\sigma-1}}\right]
$$

One should note from the wage equation (4) that in period one workers have acquired no human capital so output is zero. The surplus in that period is minus the cost of human capital acquired. The starting wage is just the worker's share in this. Therefore for the starting wage to be the same in both sectors human capital acquisition must be the same. We see from equation (12) that if $\alpha^{f} h_{0}^{f}=\alpha^{d} h_{0}^{d}$ this will be the case. We also see from equation (13) that while $\alpha^{n}$ shifts the wage profile, $h_{0}^{n}$ changes the slope. We arbitrarily choose these parameter values to demonstrate when starting wages will be the same and graph the results in Figure 1. The values are $\alpha^{d}=h_{0}^{d}=1$ and $\alpha^{f}=\frac{1}{h_{0}^{f 1}}=1.1$. There are ten periods and $\beta=0.9$. The point of the example is not that we have a strong belief in the particular parameter values chosen. Rather it is to illustrate that while a model where specific capital is more productive in the foreign sector will lead to higher wage increases in that sector, the starting value for wages depends on an arbitrary combination of technological parameters. We could easily assume other parameter values that would lead to lower or higher starting wages in the foreign sector and still have a steeper tenure profile in foreign firms. 


\section{Section III: Data and Summary Statistics}

In order to investigate whether the predictions of our theoretical model are consistent with what is observed empirically we utilise data for manufacturing firms in Ghana from the Regional Programme for Enterprise Development (RPED). ${ }^{3}$ The data we use here are for the 1998 sample, i.e., the fifth annual wave, of Ghanaian manufacturing firms. ${ }^{4}$ The initial wave of 200 firms in this survey was drawn from the 1987 Ghana Census of Manufacturing Activities, stratified by size, sector and location. ${ }^{5}$ The sectors from which the firms were chosen are Food, Textiles and Garments, Wood, and Metal, which together comprise about 70 per cent of total manufacturing employment in Ghana. ${ }^{6}$ When firms were closed down over the period they were replaced with firms in the same size, sector and location category.

The RPED data set is essentially an employer-employee matched data in that, while each firm was interviewed for information at the firm level, additionally up to ten of its workers, representative of ten broad occupation categories, were interviewed. Firm level information used in this paper are the level of profit, total employment, value of capital stock, regional location, sector, incidence of state ownership, and, most importantly, the percentage of foreign ownership of each firm. Information from the worker surveys utilized include information concerning their current and previous year earnings and employment, starting earnings and employment, and their level of human

\footnotetext{
${ }^{3}$ It is noteworthy that the Ghana data is also used by te Velde and Morrissey (2001) in their five country study, although an earlier wave with much less information than used here.

${ }^{4}$ We use only the 1998 since this last wave provides the most information at the worker level. Unfortunately one cannot link workers across waves.

${ }^{5}$ In the sampling large firms were oversampled. However, since there is no reliable source on the actual population of firms, we were not able to use weights for either our summary statistics our econometric estimation.

${ }^{6}$ In actuality the data set allows us to distinguish among ten sectors within these four main sectors.

${ }^{7}$ For the latter four years firms and workers were interviewed only in the fifth and seventh wave, but information was asked respectively for the two years prior to these dates.
} 
capital. $^{8}$ In order to ensure that our sample size was consistent across estimation models we only used data for which we had all information at the worker and firm level that we used throughout the analysis. This left us with a sample of 144 firms and 1,365 workers.

Our variable of primary interest is the ownership of the firm. ${ }^{9}$ Most previous studies of the foreign wage premium simply distinguish between firms with no foreign ownership and those with at least some, but for the latter group do not distinguish between the degree of foreign ownership. In this paper we are careful to distinguish between the degree of foreign ownership within foreign owned firms, as greater foreign ownership may also mean greater access to foreign capital and technology and better know-how. Also, greater foreign ownership may allow greater adoption of these advantages by the firm. An examination of the foreign owned firms in our sample shows that the incidence of foreign ownership is quite dispersed; of the 144 firms in the sample 34 have some foreign ownership. Of those with at least some foreign ownership the mean, minimum, maximum and standard deviation of the degree of foreign ownership are 65, 20, 100 and 22 per cent, respectively. Thus allowing foreign ownership to vary among firms in a non-dichotomous manner allows us a more precise measure of the factors associated with foreign owned firms if these depend on the degree of foreign ownership.

In Table 1 we present some summary statistics for workers in foreign and domestically owned firms. As can be seen the average wage rate in domestic firms is

\footnotetext{
${ }^{8}$ All nominal variables were converted into 1998 prices using sectoral deflators.

9 As pointed out by te Velde and Morrissey (2001), in the RPED data sets one is unable to distinguish between firms owned by foreign nationals and multinational corporations. While both groups of firms, relative to domestic firms, arguably have greater access to foreign capital and technology and better know-how, it is only the latter which is likely to benefit from firm specific assets. However, for the purpose of the present paper we simply take as given that in firms with foreign ownership firm specific human capital is more productive, the source of this feature is inconsequential.
} 
considerably lower than that for employees in foreign owned firms. ${ }^{10}$ This discrepancy already manifests itself in the starting wage of workers, and widens as workers spend more time in the firm. Part of the widening wedge is of course due to the fact that workers in foreign owned firms stay on average longer in the same firm as is apparent from the tenure means. However, even when we calculate the average per year (spent in the firm) increase in the log real wage rate from these means, we find that the wage growth per year is still larger for workers employed by foreign owned firms. The worker means, however, also show that workers in domestic firms are less educated - a factor which may, at least in part, be driving the difference in mean wages.

\section{[Table 1 bere]}

Examining some of the average characteristics of foreign relative to domestic owned firms, also given in Table 1, we find these two groups of firms differ in terms of these. Specifically, foreign owned firms are found to be substantially larger, enjoy greater profits, and have higher capital intensity than their domestic counterparts. Clearly, some of these firm level features may be driving at least some of the wage premium. For instance, Strobl and Thornton (2002) have shown for an earlier wave of the data, that there was a large firm size wage premium - a factor that is commonly known as the employer size wage effect in the labour economics literature. Also some researchers have argued that the foreign wage premium may be associated with greater profit sharing (see te Velde and Morrissey, 2001). Moreover, it is reasonable to suspect that if foreign firms have greater or better quality capital they may need to hire more skilled workers, or, as we argue, train workers more intensely. The firm means provided at least tentatively suggest that these factors may also be linked to the foreign wage premium. One should

\footnotetext{
${ }^{10}$ One should note that wages are measured as the complete compensation of the individual. In other words, earnings not only include explicit pay, but also the value of other allowances, bonuses and benefits.
} 
also note that simple correlation of these firm level variables suggest that they are all positively correlated with the degree of foreign ownership.

\section{Section IV: Econometric Evidence}

\section{Current Wages}

The summary statistics confirm the general finding in the literature of a foreign wage premium for Ghanaian manufacturing. However, they also suggest that other human capital and firm characteristics that are usually associated with higher wages may be correlated with the degree of foreign ownership. We now turn to measuring the foreign wage premium controlling for other individual and firm specific factors.

We first ran a simple OLS regression of determinants of the log of current hourly earnings only including foreign ownership as an explanatory variable as a our benchmark case, the results of which are given in the first column of Table 2. As can be seen, the ownership variable has a significant positive impact on the log hourly wage rate. At the mean of the hourly wage rate in levels, the coefficient implies that a one per cent increase of foreign ownership increases the hourly wage rate by 3.3 per cent. ${ }^{11}$

Using this initial specification as the benchmark case, we subsequently systematically added sets of explanatory variables to investigate how these may alter the foreign ownership wage premium. Firstly, the human capital model (see, e.g., Becker, 1993), posits that differences in wages should be explained by differences in human capital. We thus included all available worker characteristics that may be related to the level of human capital in the regression, namely, education dummies (9), actual work experience at the start of the job and its value squared, Ghanaian language reading ability dummy, Ghanaian language writing ability dummy, English language speaking ability 
dummy, English language reading ability dummy, simple calculation ability dummy, gender dummy, marital status dummy, and African ethnicity dummy. The results of this exercise are given in the second column of Table 2. Accordingly, the size of the coefficient is reduced substantially from 0.65 to 0.46 , although it is still highly significant. However, clearly the size of foreign wage premium remains large, implying a 2.3 per cent increase in the hourly wage rate for each additional percentage increase in foreign ownership.

We subsequently included characteristics pertaining to the job that the individual has performed, namely, tenure and its value squared, occupation dummies (19), and a set of dummies indicating whether the worker currently receives on-the-job-training or received on-the-job-training in the past, is a permanent employee, works part-time, and is a union member. As can be seen from the third column of Table 2, this set of dummies also reduces the coefficient on foreign ownership noticeably, although, again a significant and large wage premium remains.

Finally, we also included regional dummies (3), sectoral dummies (9), a state ownership dummy, profits per employee, capital intensity, and size (employment) to control for other differences across firms that may be driving the firm size wage premium. These may all arguably affect a worker's wage and be possibly unevenly distributed across firm ownership type. In particular, the extensive literature on wage determination has shown that inter-industry wage differentials, the firm size wage effect, public ownership and regional labour markets can be important factors of wage determination (see, e.g., Strobl and Thornton, 2002). Our inclusion of profits per employee also allows us to see whether rent sharing is an important feature of wage determination as is assumed in our theoretical model. From the results in the fourth

11 We also experimented with just using observations for those workers in foreign firms to investigate whether the degree of ownership mattered, not just its incidence. We found this 
column of Table 2 it is reassuring to note that greater profits per employee increases the wage rate of workers significantly, indicating that indeed, as in our model, bargaining is an important feature of earnings. We also find that greater capital intensity of the workplace increases a worker's earnings. However, while the inclusion of all of these firm level variables does lower the size of the coefficient on foreign ownership by more than 50 per cent, it remains positive and significant. In other words, our results on the current wage rate suggest that while controlling for observable human capital, job and firm characteristics across workers that there is some correlation between these and foreign ownership, they fail to explain fully the foreign ownership wage premium. ${ }^{12}$

[Table 2 bere]

According to our theoretical model the foreign wage premium arises because workers that receive on the job training receive more and/or higher quality training in foreign owned firms due to the assumed higher productivity in foreign owned firms. One would thus expect a foreign wage premium especially for those workers that are engaged in on the job training, while for other workers this is unlikely to be (as) important. ${ }^{13}$ We therefore divided our sample into those workers that currently received or have received on the job training in the past (OJT) and those that never had (N-OJT) and ran our OLS model of earnings determination including all our control variables for these separately, as given in columns 5 and 6 and of Table 2, respectively.

As can be seen, the coefficient for the N-OJT is smaller than for the overall sample and insignificant, implying that these are not characterized by a foreign ownership premium. In contrast, as is in line with our theoretical model, workers with on the job training have higher earnings the higher the degree of foreign ownership as indicated by

indeed to be the case.

12 We also investigated whether the relationship may be non-linear by including higher order terms, but in all cases these were insignificant. 
the large positive and significant coefficient on the foreign ownership. Specifically, each per cent increase in foreign ownership increases the hourly wage rate of workers with on the job training by 0.26 per cent.

\section{Starting Wages}

Our results on current earnings show that the foreign wage premium only exists for workers with on the job training, which is consistent with our theoretical model. As they spend time in the firm their wage profile will be steeper than that of their domestic firm counterparts.

We thus firstly examine how foreign ownership affects the starting wage of workers. In doing so we are faced with one particular obstacle. Although we know when a worker first started in the firm and at what wage and occupation, we only know the current degree of foreign ownership for our sample of workers. ${ }^{14}$ We thus make the assumption that foreign ownership has remained constant over time, at least in so far as the earliest starting wage is observed. ${ }^{15}$ Using the information on workers' earnings at the start of their job in the firm, we regressed the real hourly wage rate on the degree of (current) foreign ownership first for workers who have received on the job training over time in the firm, as shown in the first three columns of Table 3. Accordingly, the foreign ownership wage premium without any controls is positive, but insignificant. As we add the human capital characteristics and subsequently job and firm level controls to the

13 Of course formal on the job training is not the only route through which workers acquire human capital in a firm. Informal training and/or learning may also be important. One may expect, however, that these forms of learning are highly correlated to formal training.

${ }^{14}$ Strictly speaking for a sub-set of workers, namely those that have started working the firm in years for which we can link firm level information on foreign ownership from previous waves, we can also find the degree of foreign ownership at the start of their job. However, given the number of firms that had been added since the start of the survey so that no previous information was available and the large number of missing values across the years on foreign ownership even for those firms that are continuously observed, our sample size would have been reduced to less than a quarter of that we use for the current wage.

${ }^{15}$ For the firms for which we had earlier information on foreign ownership, it appears to have changed very little, although we can only observe foreign ownership no earlier back than six years. 
regression, ${ }^{16}$ shown in columns two and three, the size of the coefficient turns negative, but remains insignificant. As shown in the fourth and fifth column of Table 3, for the case of workers who do not receive on the job training we find a positive foreign wage premium, with and without including human capital controls. However, as soon as we add job and firm level controls the coefficient falls considerably in size and becomes insignificant. This suggests that once other factors are accounted for, workers in domestic owned firms receive the same starting wage as those in foreign firms if they do not receive job training in the future. ${ }^{17}$

One should note that similar starting wages between foreign and indigenous workers who (will) receive on the job training are consistent with our theoretical model. This can arise because of the technological parameters in the production functions of firms. It may also be that since workers at the start of the contract only share in the cost of human capital acquired in the first period, that wage differences are just too low to be picked up statistically. One could also conjecture that in developing countries like Ghana credit constraints may prevent workers from falling below a certain wage level. As stated earlier, lower wage bounds like credit constraints or minimum wages do not prevent on the job training and subsequent wage premium differences from taking place in our and other theoretical on-the-job-training models. The data in the empirical section indicates however that credit constraints are an unlikely explanation for foreign and domestic firms not having a statistically significant difference in their predicted starting wage. This can be easily seen from Table 1 where there are obvious differences in average starting

\footnotetext{
16 As firm level variables we exclude firm size, profits per employee and capital intensity as these are likely to vary considerably over time. However, even when we included current values of these variables this did not change our results significantly. Results are available from the authors.

17 One should also note that our finding of similar starting wages across ownership type also suggests that unobserved to the researcher, but observable by the employer, human capital differences across ownership type is unlikely to provide an explanation for the foreign wage premium, as these would suggest higher starting wages for foreign owned firm employees.
} 
wages between firm types, so that it is only when we control for personal and job characteristics that the difference becomes insignificant.

\section{[Table 3 here]}

\section{Wage Growth}

The evidence presented thus far shows that workers with on the job training receive a higher wage premium the greater the degree of foreign ownership when considering their current wage, but not their starting wage. This suggests that the premium is acquired as the worker spends time and trains in the foreign owned firm. In order to verify this we now examine how foreign ownership affects an individual's wage growth within a firm.

The information available to us allows us to calculate total wage growth experienced by workers since the start of the job. Clearly, workers who have spent longer time at a firm are more likely to have experienced greater wage growth for reasons such as seniority effects, greater bargaining power, amongst other things, so that this must be controlled for. One possibility is simply to calculate the average annual wage growth by dividing total wage growth by job tenure. This necessarily restricts the effects of tenure to be linear on wages, so that we instead rather use total wage growth as our dependent variable, but include tenure and its squared value as controls for time spent in the firm. Additionally, it must be pointed out that differences in tenure may also reflect differences in starting dates, and hence wage growth may capture different economic conditions at the time of the start of the job. We thus also included time dummies in all our wage growth regressions. Finally, one should note that by examining the determinants of wage growth we are able to purge any other unobservable, time invariant determinants of wages that we may have not been able to control for given the information in our data set from the regression. 
The results of our wage growth regressions are given for workers with on the job training in the first column of Table 4. The positive and significant sign on the foreign ownership variable indicates that the higher the degree of foreign ownership of a firm, the greater the growth rate of a workers' wage. We subsequently also included our set of human capital, job and firm level controls to allow for greater wage growth due to these. For example, those with greater human capital may also be more likely to become more proficient at the task they perform and hence be rewarded with greater wage growth. If these higher ability individuals are also more likely to work for firms with greater foreign ownership then this could explain the greater wage growth associated with foreign ownership. However, as can be seen from the second column of Table 6, their inclusion does not significantly alter the conclusion that greater foreign ownership results in greater earnings growth if the worker receives on the job training.

We conducted the same exercise for our sample of workers who do not receive on the job training, the results of which are provided in columns three and four of the same table. As can be seen, whether we include our human capital, job and firm controls or not, in no case does foreign ownership act to increase a worker's earnings growth. Our empirical findings are, hence, in line with the predictions of the model which suggests that workers receiving training will experience higher wage growth in foreign firms, while there should be no such differential between workers in foreign and domestic firms that do not receive training.

[Table 4 bere]

\section{Section V: Concluding Remarks}

This paper shows theoretically that one explanation for the fact that foreign firms pay higher wages than their domestic counterparts may be the provision of on-the-job training. Under the assumption that training in foreign firms is more productive than 
training in domestic firms, workers receiving training in foreign firms experience higher wage growth than trained workers in domestic firms. Our empirical analysis based on data for manufacturing firms in Ghana provides evidence that is in line with the theoretical predictions. While we find no statistically significant difference in starting wages of trained and untrained workers in foreign and domestic firms (once other individual and firm characteristics are controlled for) we find that workers receiving onthe-job training in foreign firms experience higher wage growth than workers being trained in domestic firms. By contrast, there does not appear to be any difference in wage growth between workers not receiving training in either foreign or domestic firms.

One more general conclusion to be drawn from our analysis is that host countries may benefit from the presence of foreign owned firms, particularly if they encourage them to train their workers. Apart from leading to increases in wages to workers employed by multinationals, training directly increases the host country's level of absorptive capacity by improving its stock of human capital (see, e.g., Keller, 1996). Also, movements of trained workers from foreign to domestic owned firms may cause indirect productivity spillovers to the domestic sector (see, for instance, by Fosfuri, Motta and Ronde, 2001), as workers apply their new skills in domestically owned firms or set up their own business. 


\section{References}

Acemoglu, Daron and Jörn-Steffen Pischke (1999a), "The structure of wages and investment in general training", Journal of Political Economy, Vol. 107, pp. 539-572.

Acemoglu, Daron and Jörn-Steffen Pischke (1999b), "Beyond Becker: Training in imperfect labour markets", Economic Joumal, Vol. 109, pp. F112-F142.

Aitken, Brian, Ann Harrison and Robert E. Lipsey (1996), "Wages and foreign ownership: a comparative study of Mexico, Venezuela, and the United States", Journal of International Economics, Vol. 40, pp. 345-371.

Becker, Gary (1993), Human capital: a theoretical and empirical analysis with special reference to education. Third edition. Chicago: Chicago University Press.

Caves, Richard E. (1996), Multinational Enterprise and Economic Analysis. Second Edition. Cambridge: Cambridge University Press.

Doms, Mark E. and J. Bradford Jensen (1998): "Comparing wages, skills, and productivity between domestically and foreign-owned manufacturing establishments in the United States", in R. Baldwin, R. Lipsey and J.D. Richardson (eds.), Geography and Ownership as Bases for Economic Accounting, Chicago: Chicago University Press, pp. 235-255.

Feliciano, Zadia and Robert E. Lipsey (1999): "Foreign ownership and wages in the United States, 1987-1992”, NBER Working Paper No. 6923.

Fosfuri, Andrea, Massimo Motta and Thomas Ronde (2001): "Foreign Direct Invesment and Spillovers Through Workers' Mobility", Journal of International Economics, Vol. 53, pp. 205-222.

Gershenberg, Irving (1987): "The training and spread of managerial know-how: a comparative analysis of multinational and other firms in Kenya", World Development, Vol. 15, pp. 931-939.

Girma, Sourafel, David Greenaway and Katharine Wakelin (2001), "Who benefits from foreign direct investment in the UK?”, Scottish Journal of Political Economy, Vol. 48, pp. 119133.

Globerman, Steven, John C. Ries and Ilan Vertinsky (1994), “The economic performance of foreign affiliates in Canada", Canadian Journal of Economics, Vol. 27, pp. 143-156.

Griffith, Rachel and Helen Simpson (2002), "Characteristics of foreign-owned firms in British manufacturing", in R. Blundell, D. Card and R. Freeman (eds.), Creating a Premier League Economy, Chicago: Chicago University Press, forthcoming.

Hashimoto, Masinori (1981), "Firm Specific Human Capital as a Shared Investment", American Economic Review, Vol. 71, pp. 475-482.

Keller, Wolfgang (1996): "Absorptive Capacity: Understanding the Creation and Acquisition of Technology in Development", Journal of Development Economics, Vol. 49, pp. 199-227.

Lim, David (1977), "Do foreign companies pay higher wages than their local counterparts in Malaysian manufacturing?", Journal of Development Economics, Vol. 4, pp. 5566.

Lipsey, Robert E. and Fredrik Sjöholm (2001), "Foreign direct investment and wages in Indonesian manufacturing”, NBER Working Paper No. 8299. 
Malcolmson, J.M. (1999), “Individual Employment Contracts” in O. Ashenfelter and D. Card (eds.), Handbook of Labor Economics, Volume 3B, Amsterdam: Elsevier Science.

Sousa, Nuno (2001), "Multinationals and Technology Transfer through Labour Training", mimeo, University of Nottingham (presented at a CEPR Workshop on Labour Market Effects of European Foreign Investments, Dublin, July 2001).

Strobl, Eric and Robert Thornton (2002), "Do large employers pay more in developing countries? The case of five African countries", CREDIT Research Paper 02/01, University of Nottingham.

Sutton, John (1986), "Non-Cooperative Bargaining Theory: An Introduction", Review of Economic Studies, Vol. 53, pp. 709-724.

Te Velde, Dirk Willem and Oliver Morrissey (2001), "Foreign ownership and wages: evidence from five African countries", CREDIT Research Paper 01/19, University of Nottingham. 
Table 1: Summary Statistics (Means)

\begin{tabular}{lcc}
\hline & Foreign & Domestic \\
\hline Log(Current Wage) & 1.56 & 1.05 \\
Log(Starting Wage) & 1.36 & 0.99 \\
Wage Growth & 0.20 & 0.06 \\
Tenure (years) & 8.3 & 5.4 \\
Years Schooling & 11.3 & 10.5 \\
L & 244 & 54 \\
Capital/L & 0.11 & 0.03 \\
Profit/L & 0.009 & 0.002 \\
\hline
\end{tabular}

Notes:

1. All nominal variables were converted to real values.

2. Value Added, Capital, and Profits in millions.

Table 2: Current Wage

\begin{tabular}{lcccccc}
\hline & $\mathbf{( 1 )}$ & $\mathbf{( 2 )}$ & $\mathbf{( 3 )}$ & $\mathbf{( 4 )}$ & $\mathbf{( 5 )}$ & $\mathbf{( 6 )}$ \\
\hline FOR & $0.649^{* * *}$ & $0.458^{* * *}$ & $0.377^{* * *}$ & $0.085^{*}$ & $0.262^{* *}$ & 0.072 \\
& $(0.071)$ & $(0.050)$ & $(0.048)$ & $(0.047)$ & $(0.131)$ & $(0.051)$ \\
PROF/L & --- & --- & --- & $11.210^{* * *}$ & $14.070^{* * *}$ & $11.502^{* * *}$ \\
& & & & $(1.539)$ & $(3.175)$ & $(1.762)$ \\
CAP/L & --- & --- & --- & $0.761^{* * *}$ & $0.671^{* * *}$ & $0.782^{* * *}$ \\
& & & & $(0.135)$ & $(0.234)$ & $(0.169)$ \\
Constant & $1.089^{* * *}$ & $3.183^{* * *}$ & $2.641^{* * *}$ & $1.386^{* * *}$ & -0.709 & $0.945^{* * *}$ \\
& $(0.025)$ & $(0.131)$ & $(0.256)$ & $(0.309)$ & $(0.551)$ & $(0.248)$ \\
Human Capital & No & Yes & Yes & Yes & Yes & Yes \\
Job Charact. & No & No & Yes & Yes & Yes & Yes \\
Firm Charact. & No & No & No & Yes & Yes & Yes \\
\hline Sample & Total & Total & Total & Total & OJT & N-OJT \\
Observations & 1364 & 1364 & 1364 & 1364 & 331 & 1033 \\
F( $\left.\boldsymbol{\beta}_{j}=\mathbf{0}\right)$ & $93.9^{* * *}$ & $52.7^{* * *}$ & $39.2^{* * *}$ & $41.4^{* * *}$ & $12.9 * * *$ & $31.1 * * *$ \\
R-squared & 0.06 & 0.46 & 0.58 & 0.66 & 0.73 & 0.66 \\
\hline
\end{tabular}

Notes:

1. Robust standard errors in parentheses.

2. Dependent variable is the log of wage rate.

3. $\quad * * *, * *$, and * signify one, five and ten per cent significance levels, respectively.

4. Human capital characteristics include: education dummies (9), actual work experience at the start of the job and its value squared, Ghanian language reading ability dummy, Ghanian language writing ability dummy, English language speaking ability dummy, English reading ability dummy, simple calculation ability dummy, gender dummy, marital status dummy, and African ethnicity dummy.

5. Job characteristics include tenure and its value squared, occupation dummies (19), current on-theob-training dummy, past on-the-job-training dummy, permanent worker dummy, and union status dummy.

6. Firm characteristics include regional dummies (3), sectoral dummies (9), state ownership dummy, and size (employment). 
Table 3: Starting Wage

\begin{tabular}{lcccccc}
\hline & $\mathbf{( 1 )}$ & $\mathbf{( 2 )}$ & $\mathbf{( 3 )}$ & $\mathbf{( 4 )}$ & $\mathbf{( 5 )}$ & $\mathbf{( 6 )}$ \\
\hline FOR & 0.212 & -0.063 & -0.165 & $0.304^{* *}$ & $0.214^{*}$ & 0.096 \\
& $(0.294)$ & $(0.295)$ & $(0.330)$ & $(0.123)$ & $(0.114)$ & $(0.124)$ \\
Constant & $0.808^{* * *}$ & $6.916^{* * *}$ & -0.150 & $1.291^{* * *}$ & $6.511^{* * *}$ & $11.141^{* * *}$ \\
& $(0.218)$ & $(0.378)$ & $(1.254)$ & $(0.068)$ & $(1.646)$ & $(1.584)$ \\
Human Capital & No & Yes & Yes & No & Yes & Yes \\
Job Charact. & No & No & Yes & No & No & Yes \\
Firm Charact. & No & No & Yes & No & No & Yes \\
\hline Sample & OJT & OJT & OJT & N-OJT & N-OJT & N-OJT \\
Observations & 331 & 331 & 331 & 1033 & 1033 & 1033 \\
$\mathbf{F}\left(\beta_{j}=\mathbf{0}\right)$ & $6.3^{* * *}$ & $5.5^{* * *}$ & $4.7^{* * *}$ & $6.1^{* * *}$ & $9.5^{* * *}$ & $8.0^{* * *}$ \\
$\mathbf{R}^{\mathbf{2}}$ & 0.37 & 0.47 & 0.59 & 0.17 & 0.34 & 0.43 \\
\hline
\end{tabular}

Notes:

1. Robust standard errors in parantheses.

2. Dependent variable is the log of wage rate.

3. $* * *, * *$, and $*$ signify one, five and ten per cent significance levels, respectively.

4. TIME are year dummies for starting year.

5. Human capital characteristics include: education dummies (9), actual work experience at the start of the job and its value squared, Ghanian language reading ability dummy, Ghanian language writing ability dummy, English language speaking ability dummy, English reading ability dummy, simple calculation ability dummy, gender dummy, marital status dummy, and African ethnicity dummy.

6. Job characteristics include tenure and its value squared, starting occupation dummies (19), permanent worker dummy, and union status dummy.

7. Firm characteristics include regional dummies (3), sectoral dummies (9), state ownership dummy, and size (employment). 
Table 4: Wage Growth

\begin{tabular}{lcccc}
\hline & $\mathbf{( 1 )}$ & $\mathbf{( 2 )}$ & $\mathbf{( 3 )}$ & $\mathbf{( 4 )}$ \\
\hline FOR & $0.512^{*}$ & $0.546^{*}$ & 0.150 & 0.181 \\
& $(0.278)$ & $(0.316)$ & $(0.107)$ & $(0.122)$ \\
Constant & -0.054 & $-3.670^{* * *}$ & -8.174 & $-16.65^{* * *}$ \\
& $(0.148)$ & $(1.083)$ & $(5.367)$ & $(5.394)$ \\
TIME & Yes & Yes & Yes & Yes \\
Human Capital & No & Yes & No & Yes \\
Job \& Firm Charact. & No & Yes & No & Yes \\
\hline Sample & OJT & OJT & N-OJT & N-OJT \\
Observations & 331 & 331 & 1033 & 1033 \\
F( $\left.\beta_{\mathbf{j}}=\mathbf{0}\right)$ & $6.4^{* * *}$ & $3.3^{* * *}$ & $6.4^{* * *}$ & $3.9^{* * *}$ \\
R-squared & 0.38 & 0.56 & 0.18 & 0.30 \\
\hline
\end{tabular}

Notes:

1. Robust standard errors in parantheses.

2. Dependent variable is the wage growth rate.

3. $\quad * * *, * *$, and $*$ signify one, five and ten per cent significance levels, respectively.

4. TIME are year dummies for starting year.

5. Human capital characteristics include: education dummies (9), actual work experience at the start of the job and its value squared, Ghanian language reading ability dummy, Ghanian language writing ability dummy, English language speaking ability dummy, English reading ability dummy, simple calculation ability dummy, gender dummy, marital status dummy, and African ethnicity dummy.

6. Job characteristics include tenure and its value squared, starting occupation dummies (19), current occupation dummmies (19), permanent worker dummy, and union status dummy.

7. Firm characteristics include regional dummies (3), sectoral dummies (9), and state ownership dummy. 
Figure 1: Development of Foreign and Domestic Wages

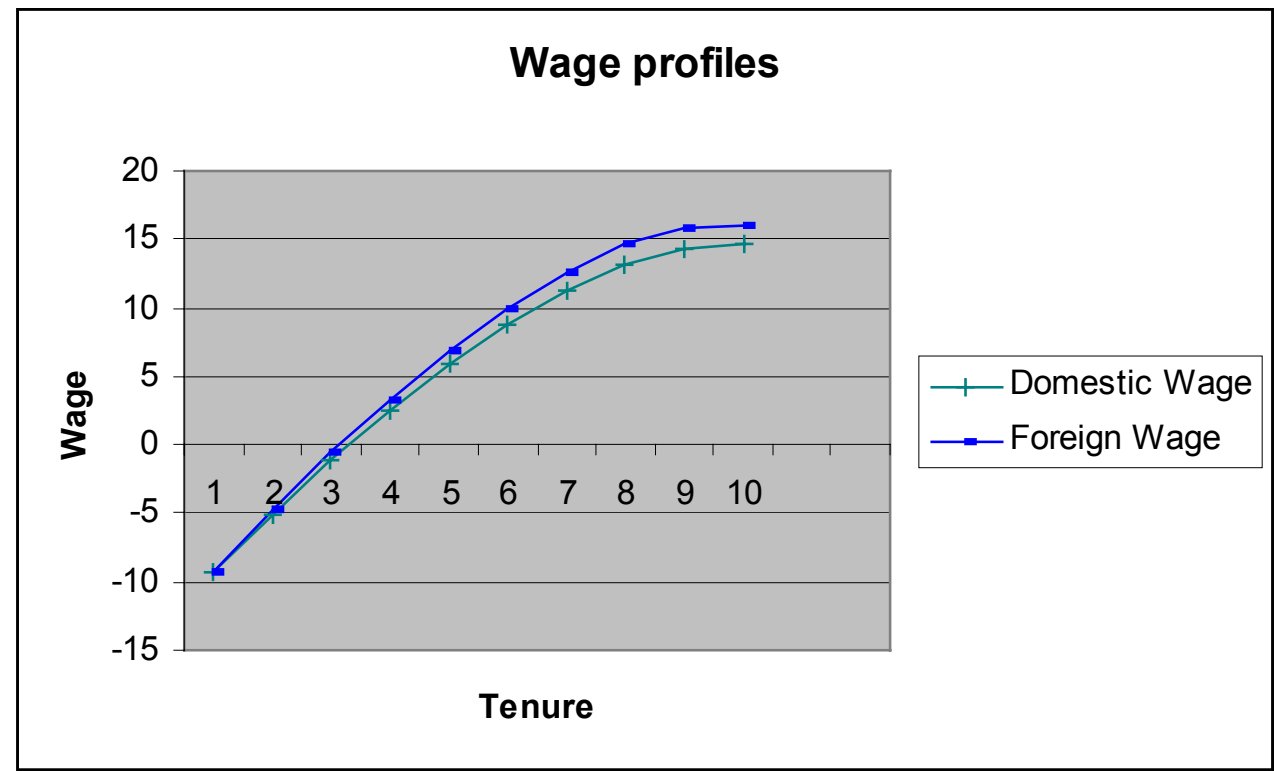




\section{Appendix}

\section{The solution to the bargaining game}

Table A.1 shows how the bargain is reached in the final period game for a standard one period bargaining game. If $\delta^{w}$ and $\delta^{f}$ are small the maximum number of offers is approximately $n \approx 1 / 2\left[\delta^{f}+\delta^{w}\right]$. We can use backward induction to see that the first offer that is made will be accepted.

Next we move to period $T$-1. Since the workers' human capital increases as each period progresses, this necessitates the renegotiation of the contract in each period as it arises. At the beginning of period $T-1$ both workers anticipate the return specified in the above table for period $T$. The return is conditional on $H_{T}$ which in turn is dependent on $b_{T-1}$. We assume that a delay in reaching a bargain in period $T-1$ reduces the accumulation of human capital in that period. This reduces the starting human capital and output in period T. In particular offer $(n-\imath)$ in period $T-1$ reduces the workers period T payoff by $L_{T-1}^{w(n-i)}$ and the firms period $T$ payoff by $L_{T-1}^{f(n-i)}$.

The wage for period T-1 is derived by backward induction in Table A.2. The worker makes offer $n-1$ and must offer enough such that the firm cannot gain from delaying. If the firm delays the wage is zero for that period and the subsequent period profit falls by $L_{T-1}^{f(n-1)}$. The worker can demand a payment of slightly less than this amount from the firm and be confident the offer will not be rejected. In addition the worker keeps all the remaining output of $\delta^{w} f\left(H_{T-1}\right)$ if a bargain is struck at the $n-1$ offer. The firm makes offer $n-2$ and offers slightly less to the worker than they would get by waiting to $n-1$. Once again the wage and profit levels given in the table are solved by backward induction. 
Note that while the $L_{T-j}^{f(n-i)}$ and $L_{T-j}^{w(n-i)}$ terms enter the wage and profit term at each stage they will drop out if we make an additional assumption. Let us call the length of time it takes for both workers and firms to make an offer a round. Round one is the first offer by the firm and the worker, so each round takes a length $\delta^{w}+\delta^{f}$. The reduction in period $T$ output associated with the loss in human capital accumulation (in period T-1) caused by round $i$ is $\lambda^{i}{ }_{T-1} F\left(H_{T}\right)$. We assume that within any round the loss in future output associated with delay caused by the worker's offer is the fraction of the length of the round taken by the workers offer:

$$
\frac{\delta^{w}}{\delta^{w}+\delta^{f}} \lambda_{T-1}^{i} F\left(H_{T}\right)
$$

The loss in future output resulting from the time a firm takes to make an offer is the fraction of the length of the round taken by the firms offer:

$$
\frac{\delta^{f}}{\delta^{w}+\delta^{f}} \lambda_{T-1}^{i} F\left(H_{T}\right)
$$

Using these expressions combined with the share of period $T$ output earned by workers and firms we calculate the loss in the firm's future payoffs from making offer $n-1$ in period $T-1$ as

$$
L_{T-1}^{f(n-1)}=\frac{\delta^{w} \delta^{f}}{\left(\delta^{w}+\delta^{f}\right)^{2}} \lambda_{T-1}^{n-1} F\left(H_{T}\right)
$$

The loss in the workers future payoff from offer $n-2$ in period $T-1$ is

$$
L_{T-1}^{w(n-2)}=\frac{\delta^{w} \delta^{f}}{\left(\delta^{w}+\delta^{f}\right)^{2}} \lambda_{T-1}^{n-1} F\left(H_{T}\right)
$$

We can calculate these loss terms in the same way for each round and see that they cancel out such that the offers in period $T-1$ are the same as in period $T$ at each offer except conditional on (T-1) human capital. 
We go back to period T-2 next and a similar argument to that in period T-1 holds. Any round of offers, say round $i$, reduces the accumulation of human capital in $T$ 2 which reduces output in the subsequent periods by an amount $\eta_{T-2}^{i} F\left(H_{T-1}\right)+\lambda^{i}{ }_{T-2} F\left(H_{T}\right)$. We assume as we did in period T-1, that the share of the loss in output during the worker's and firm's offers are $\delta^{w} /\left(\delta^{w}+\delta^{f}\right)$ and $\delta^{f} /\left(\delta^{w}+\delta^{f}\right)$ respectively. We can see that the wage in period T-2 or indeed in any period $T-i$ is

$$
w_{T-i}=\frac{\delta^{w}}{\delta^{w}+\delta^{f}} F\left(H_{T-i}\right)=\frac{\delta^{w}}{\delta^{w}+\delta^{f}}\left[G\left(\sum_{j=1}^{T-i} h_{j}\right)-c\left(h_{T-i}\right)\right]
$$

The profit in period $T-i$ is

$$
\frac{\delta^{F}}{\delta^{w}+\delta^{f}} F\left(H_{T-i}\right)
$$


Table A1: Period T offers

\begin{tabular}{|l|l|l|l|}
\hline Offer number & Surplus & $w_{T}$ & $\pi_{T}$ \\
\hline$n \approx \frac{2}{\left[\delta^{f}+\delta^{w}\right]}$ & 0 & 0 & 0 \\
\hline $\mathrm{n}-1$ & & & \\
\hline $\mathrm{n}-2$ & {$\left[\delta^{w}+\delta^{f}\right] f\left(H_{T}\right)$} & $\delta^{w} f\left(H_{T}\right)$ & $\delta^{f} f\left(H_{T}\right)$ \\
\hline $\mathrm{n}-3$ & {$\left[2 \delta^{w}+\delta^{f}\right] f\left(H_{T}\right)$} & $2 \delta^{w} f\left(H_{T}\right)$ & $\delta^{f} f\left(H_{T}\right)$ \\
\hline $\mathrm{n}-4$ & {$\left[2 \delta^{w}+2 \delta^{f}\right] f\left(H_{T}\right)$} & $2 \delta^{w} f\left(H_{T}\right)$ & $2 \delta^{f} f\left(H_{T}\right)$ \\
\hline$\ldots$ & & & \\
\hline$\ldots$ & & $\frac{\delta^{w}}{\delta^{w}+\delta^{f}} f\left(H_{T}\right)$ & $\frac{\delta^{f}}{\delta^{w}+\delta^{f}} f\left(H_{T}\right)$ \\
\hline 1 & $f\left(H_{T}\right)$ & \multicolumn{2}{|l}{} \\
\hline
\end{tabular}

TableA2: Period T-1 offers

\begin{tabular}{|c|c|c|c|}
\hline Offer number & Surplus & $w_{T}$ & $\pi_{T}$ \\
\hline$n \approx \frac{2}{\left[\delta^{f}+\delta^{w}\right]}$ & 0 & 0 & 0 \\
\hline $\mathrm{n}-1$ & $\delta^{w} f\left(H_{T-1}\right)$ & $\delta^{w} f\left(H_{T-1}\right)+L_{T-1}^{f(n-1)}$ & $-L_{T-1}^{f(n-1)}$ \\
\hline$n-2$ & {$\left[\delta^{w}+\delta^{f}\right] f\left(H_{T-1}\right)$} & $\delta^{w} f\left(H_{T-1}\right)+L_{T-1}^{f(n-1)}-L_{T-1}^{w(n-2)}$ & $\delta^{f} f\left(H_{T-1}\right)-L_{T-1}^{f(n-1)}+L_{T-1}^{w(n-2)}$ \\
\hline$n-3$ & {$\left[2 \delta^{w}+\delta^{f}\right] f\left(H_{T-1}\right)$} & $2 \delta^{n f} f\left(H_{T-1}\right)+L_{T-1}^{f(n-1)}+L_{T-1}^{f(n-3)}-L_{T-1}^{n(n-2)}$ & $\delta^{f} f\left(H_{T-1}\right)-I_{T-1}^{f(n-1)}-I_{T-1}^{f(n-3)}+L_{T-1}^{n(n-2)}$ \\
\hline$n-4$ & {$\left[2 \delta^{w}+2 \delta^{f}\right] f\left(H_{T-1}\right)$} & $2 \delta^{n f} f\left(H_{T-1}\right)+L_{T-1}^{f(n-1)}+L_{T-1}^{f(n-3)}-L_{T-1}^{m(n-2)}-L_{T-1}^{m(n-4)}$ & 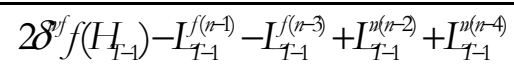 \\
\hline \multicolumn{4}{|l|}{$n-5$} \\
\hline$\ldots$ & $\ldots$ & $\ldots$ & $\ldots$ \\
\hline 1 & $f\left(H_{T-1}\right)$ & $\frac{\delta^{w}}{\delta^{w}+\delta^{f}} f\left(H_{T-1}\right)$ & $\frac{\delta^{f}}{\delta^{w}+\delta^{f}} f\left(H_{T-1}\right)$ \\
\hline
\end{tabular}




\section{IZA Discussion Papers}

\begin{tabular}{|c|c|c|c|c|}
\hline No. & Author(s) & Title & Area & Date \\
\hline 575 & $\begin{array}{l}\text { H. Antecol } \\
\text { D. A. Cobb-Clark } \\
\text { S. J. Trejo }\end{array}$ & $\begin{array}{l}\text { Human Capital and Earnings of Female } \\
\text { Immigrants to Australia, Canada, and the } \\
\text { United States }\end{array}$ & 5 & $09 / 02$ \\
\hline 576 & $\begin{array}{l}\text { M. Fertig } \\
\text { C. M. Schmidt } \\
\text { H. Schneider }\end{array}$ & $\begin{array}{l}\text { Active Labor Market Policy in Germany - } \\
\text { Is There a Successful Policy Strategy? }\end{array}$ & 6 & $09 / 02$ \\
\hline 577 & $\begin{array}{l}\text { K. Ariga } \\
\text { G. Brunello }\end{array}$ & $\begin{array}{l}\text { Are the More Educated Receiving More } \\
\text { Training? Evidence from Thailand }\end{array}$ & 2 & $09 / 02$ \\
\hline 578 & $\begin{array}{l}\text { I. N. Gang } \\
\text { F. L. Rivera-Batiz } \\
\text { M.-S. Yun }\end{array}$ & $\begin{array}{l}\text { Economic Strain, Ethnic Concentration and } \\
\text { Attitudes Towards Foreigners in the European } \\
\text { Union }\end{array}$ & 1 & $09 / 02$ \\
\hline 579 & $\begin{array}{l}\text { I. N. Gang } \\
\text { M.-S. Yun }\end{array}$ & $\begin{array}{l}\text { Decomposing Inequality Change in East } \\
\text { Germany During Transition }\end{array}$ & 4 & $09 / 02$ \\
\hline 580 & $\begin{array}{l}\text { I. N. Gang } \\
\text { J. Landon-Lane } \\
\text { M.-S. Yun }\end{array}$ & $\begin{array}{l}\text { Gender Differences in German Upward Income } \\
\text { Mobility }\end{array}$ & 1 & $09 / 02$ \\
\hline 581 & $\begin{array}{l}\text { P. Cahuc } \\
\text { F. Malherbet }\end{array}$ & $\begin{array}{l}\text { Unemployment Compensation Finance and } \\
\text { Labor Market Rigidity }\end{array}$ & 5 & $09 / 02$ \\
\hline 582 & $\begin{array}{l}\text { P. Cahuc } \\
\text { C. Gianella } \\
\text { D. Goux } \\
\text { A. Zylberberg }\end{array}$ & $\begin{array}{l}\text { Equalizing Wage Differences and Bargaining } \\
\text { Power: Evidence from a Panel of French Firms }\end{array}$ & 6 & $09 / 02$ \\
\hline 583 & $\begin{array}{l}\text { P. Cahuc } \\
\text { F. Fontaine }\end{array}$ & $\begin{array}{l}\text { On the Efficiency of Job Search with Social } \\
\text { Networks }\end{array}$ & 5 & $09 / 02$ \\
\hline 584 & $\begin{array}{l}\text { C. J. Heinrich } \\
\text { P. R. Mueser } \\
\text { K. R. Troske }\end{array}$ & $\begin{array}{l}\text { Welfare to Temporary Work: Implications for } \\
\text { Labor Market Outcomes }\end{array}$ & 3 & $09 / 02$ \\
\hline 585 & $\begin{array}{l}\text { M. Cervellati } \\
\text { U. Sunde }\end{array}$ & $\begin{array}{l}\text { Human Capital Formation, Life Expectancy and } \\
\text { the Process of Economic Development }\end{array}$ & 3 & $09 / 02$ \\
\hline 586 & $\begin{array}{l}\text { P. Díaz-Vázquez } \\
\text { D. Snower }\end{array}$ & $\begin{array}{l}\text { On-the Job Training and the Effects of Insider } \\
\text { Power }\end{array}$ & 3 & $09 / 02$ \\
\hline 587 & $\begin{array}{l}\text { H. Bonin } \\
\text { W. Kempe } \\
\text { H. Schneider }\end{array}$ & $\begin{array}{l}\text { Kombilohn oder Workfare? Zur Wirksamkeit } \\
\text { zweier arbeitsmarktpolitischer Strategien }\end{array}$ & 3 & $09 / 02$ \\
\hline 588 & M. Frölich & $\begin{array}{l}\text { Nonparametric IV Estimation of Local Average } \\
\text { Treatment Effects with Covariates }\end{array}$ & 6 & $09 / 02$ \\
\hline 589 & $\begin{array}{l}\text { S. Jurajda } \\
\text { K. Terrell }\end{array}$ & $\begin{array}{l}\text { Job Growth in Early Transition: Comparing Two } \\
\text { Paths }\end{array}$ & 4 & $09 / 02$ \\
\hline 590 & $\begin{array}{l}\text { H. Görg } \\
\text { E. Strobl } \\
\text { F. Walsh }\end{array}$ & $\begin{array}{l}\text { Why Do Foreign-Owned Firms Pay More? } \\
\text { The Role of On-the-Job Training }\end{array}$ & 2 & $10 / 02$ \\
\hline
\end{tabular}

An updated list of IZA Discussion Papers is available on the center's homepage www.iza.org. 